\title{
Effect of Blanching Pretreatments on the Physicochemical and Drying Characteristics of Chui Jhal (Piper chaba H.) Stem
}

\author{
Rahmatuzzaman Rana ${ }^{1, *}$, Aminul Islam ${ }^{1}$, Ashfak Ahmed Sabuz ${ }^{2}$, Mehedi Hasan ${ }^{1}$, Rowshon Ara ${ }^{1}$ \\ ${ }^{1}$ Department of Food Engineering and Tea Technology, Shahjalal University of Science and Technology, Sylhet, Bangladesh. \\ ${ }^{2}$ Postharvest Technology Division, Bangladesh Agricultural Research Institute, Gazipur, Bangladesh.
}

\begin{abstract}
How to cite this paper: Rahmatuzzaman Rana, Aminul Islam, Ashfak Ahmed Sabuz, Mehedi Hasan, Rowshon Ara. (2020) Effect of Blanching Pretreatments on the Physicochemical and Drying Characteristics of Chui Jhal (Piper chaba H.) Stem. International Journal of the Science of Food and Agriculture, 4(4), 482-491.
\end{abstract} DOI: $10.26855 /$ ijfsa.2020.12.017

Received: November 25, 2020

Accepted: December 20, 2020

Published: December 24, 2020

*Corresponding author: Rahmatuzzaman Rana, Department of Food Engineering and Tea Technology, Shahjalal University of Science and Technology, Sylhet, Bangladesh.

Email: rzaman-fet@sust.edu

\begin{abstract}
The research aimed to determine the effect of blanching pretreatment before drying at different temperatures and the chui jhal stem's physicochemical quality. Blanching methods like hot water blanching (HWB) at $90{ }^{\circ} \mathrm{C}$ for 3 minutes, steam blanching (SB) for 5 minutes, and microwave blanching (MWB) at 600 watts for 120 seconds were applied before hot air drying at $50{ }^{\circ} \mathrm{C}, 60{ }^{\circ} \mathrm{C}$, and $70{ }^{\circ} \mathrm{C}$ at a constant airflow velocity of $1.5 \mathrm{~m} / \mathrm{s}$ and relative humidity $50 \%$. Physical deterioration of pretreated samples was lower than untreated samples, affecting the amount of nutritional retention. MWB treated sample showed maximum shrinkage and contained low ascorbic acid and total polyphenol content, but preserved better color and capsaicin content. The shrinkage percentage was found lower in SB samples and HB samples, but the former retained more ascorbic acid, total polyphenol, and capsaicin relative to all pretreatment. The experimental data on moisture loss were fitted to select drying models, namely Lewis, Henderson, Pabis, and Page. The determination coefficient $\left(\mathrm{R}^{2}\right)$ and root mean square error (RMSE) values of all models were compared. The Page model was considered most suitable for describing the drying characteristics of chui jhal stem. The page model had a good fitting of data with a high $\mathrm{R}^{2}$ value $(>0.98)$, and low root mean square of error RMSE $(<0.07)$. The percentage of nutrition retention was affected by blanching physical treatment, which affects the physical structure and various nutrient content and drying time.
\end{abstract}

\section{Keywords}

Chui Jhal, Blanching, Hot Air Drying, Kinetics, Capsaicin, Quality Parameters

\section{Introduction}

Chui jhal (Piper chaba H.) is a spicy vegetable that belongs to the family Piperaceae and is mostly used in the southern region of Bangladesh and West Bengal, and Tripura in India. It is also known as Java long pepper or Choi Jhal, found in warmer areas of Asia like Srilanka, Malaysia, Indonesia, and Singapore [1, 2]. The stem is the main part used as vegetables and spicy condiments in fish and meat dishes. The plant's stem bark contains unique chabamide piperine dimer and alkanoid, which has antimicrobial and pharmacological properties [3]. Nevertheless, it has a high moisture content (approximately 88.5\% wet basis) at harvest and cannot be stored for more than a few days at ambient conditions.

Drying is an ancient and effective technique for increasing vegetable shelf-life by limiting moisture to a low level of activity to prevent the growth of microorganisms and inhibit other moisture degradation reactions [4]. However, the quality degradation of food submitted to drying, resulting from physical, chemical, and biochemical changes, is high 
such as shrinkage, case hardening, and discoloration. The high drying temperature can cause complete loss of vitamin C and phenolic compounds in several fruits [5]. Fruits and vegetables are often pre-treated before drying to reduce drying time, which reduces energy consumption and maintains product quality [6]. Blanching is one of the physical pretreatment methods mostly used prior to different preservation processes such as drying, canning, freezing, and determines product quality [7]. Blanching not only inactivates the enzymes, but it also causes superficial micro-cracks, which can increase the transfer of moisture during the drying process [8]. Several researchers have found that combining drying with various pretreatments provides adequate efficiency of production.

Conventional hot water blanching inactivates quality degrading enzymes and destroys vegetative microbial cells, enabling stability and product quality retention during storage [9]. To minimize nutrient losses, particularly water-soluble nutrients and solids dissolve in hot water and reduce wastewater, steam blanching systems were designed to substitute hot water blanching [10]. However, during the steam blanching process, tissue softening and unnecessary quality changes sometimes result from long heating times due to lower heat transfer in steam blanching, mainly when steam velocity is minimal. To mitigate such disadvantages, many blanching technologies have been developed, such as microwave blanching (MWB), Providing benefits such as volumetric heating, minimal loss of nutrients, and high-quality products [11]. However, tissue softening and unnecessary quality changes often result from long heating times during the steam blanching process due to lower heat transfer in steam blanching, mainly when steam velocity is very low.

These blanching methods significantly influence the retention of quality parameters and mitigate drying time, which can be studied through drying rate and drying behaviour. Page, Henderson-Pabis, and Lewis model is widespread and used for mathematical modelling to explain drying kinetics. However, to our best knowledge, no studies were conducted before on chui jhal to observe the effect of blanching pretreatment on drying rate and physicochemical properties and bioactive components. The aim of our study was to quantify the impact of hot water blanching $\left(90{ }^{\circ} \mathrm{C}, 5 \mathrm{~min}\right)$, steam blanching (1 min), and microwave blanching $(600 \mathrm{~W}, 120 \mathrm{sec})$ on physicochemical properties and bioactive components of chui jhal at different drying temperature $\left(50{ }^{\circ} \mathrm{C}, 60^{\circ} \mathrm{C}\right.$, and $\left.70^{\circ} \mathrm{C}\right)$. Drying kinetics was also evaluated to find out suitable kinetic model.

\section{Methods}

\subsection{Raw Materials}

The Fresh chui jhal (Piper chaba) stems were collected from the local market of Khulna, Bangladesh. Visual defective, diseased, damaged samples were removed to minimize biological variability. All of the samples were not uniform in length, diameter, and weight.

\subsection{Pretreatments}

The samples were cleaned, and all extraneous materials were removed and cut into $3 \mathrm{~mm}$ slices using a sharp knife. Three types of blanching pretreatments were applied before drying. Total samples were divided into four batches, where the first one was untreated. The hot water blanching (HWB) was done at $90{ }^{\circ} \mathrm{C}$ for 5 min [12], water steam blanching (SB) for 1 min [13], and microwave blanching (MWB) at 600 watts for 120 sec [14]. All samples were cooled at room temperature, removing surface water using absorbent paper.

\subsection{Hot Air Drying}

Samples were placed in a perforated tray in a single thin layer. The hot air dryer (Jeio Tech, ModelOF-21E, Korea) was maintained at $50{ }^{\circ} \mathrm{C}, 60^{\circ} \mathrm{C}$ and $70{ }^{\circ} \mathrm{C}$ with a constant humidity of $\%$ and air flow rate of $1.5 \mathrm{~m} / \mathrm{s}$. The dryer was set to be the selected temperature for around 30 minutes before starting the drying process to achieve stable conditions. Each batch was taken to dry about $50 \mathrm{~g}$ triplicate samples. Sample weight loss was reported every 30 min interval until $2 \mathrm{hr}$. Then weight loss was reported at $1 \mathrm{hr}$ intervals for $6 \mathrm{hr}$ total. Experiments were repeated thrice, and the average moisture ratio for each pretreatment was used to estimate the moisture ratio and drying rate. Moisture ratio (MR) was determined using the following formula:

$$
\mathrm{MR}=\frac{\boldsymbol{M}-\boldsymbol{M} \boldsymbol{e}}{\boldsymbol{M o}-\boldsymbol{M e}}
$$

where $\mathrm{M}$ moisture content of the sample in real time, Mo is the initial moisture content and Me is the equilibrium moisture content.

\subsection{Drying Kinetics}

The following drying kinetics equations (Table 1) were used to fit chui jhal samples' experimental drying results. Drying curves were drawn as a function of time and dimensionless moisture ratio (MR). 
Table 1. Drying kinetics equations

\begin{tabular}{cc}
\hline Equation & Reference \\
\hline $\mathrm{MR}=\exp (-\mathrm{k} \times \mathrm{t})$ & Lewis (1921) \\
$\mathrm{MR}=\exp \left(-\mathrm{k} \times \mathrm{t}^{\mathrm{n}}\right)$ & Page (1949) \\
$\mathrm{MR}=\mathrm{a} \times \exp (-\mathrm{k} \times \mathrm{t})$ & Henderson and Pabis (1961) \\
\hline
\end{tabular}

The correlation coefficient $\left(\mathrm{R}^{2}\right)$ can be determined using the following formula (2) to evaluate the linear relationship between measured and expected values:

$$
\mathrm{R}^{2}=\frac{\sum_{i=1}^{N}\left(M R_{i, \text { exp }}-M R_{i, \text { exp }, \text { mean }}\right)^{2}-\sum_{i=1}^{N}\left(M R_{i, \text { pre }}-M R_{i, \text { exp }}\right)^{2}}{\sum_{i=1}^{N}\left(M R_{i, \text { exp }}-M R_{i, \text { exp }, \text { mean }}\right)^{2}}
$$

where MRi,exp stands for the experimental moisture ratio found in any measurement, MRi,pre is the predicted moisture ratio for this measurement and $\mathrm{N}$ is the total number of observations.

In order to estimate the fitting efficiency, the root mean square error (RMSE) was also calculated using the following equation (3).

$$
R M S E=\sqrt{\frac{\sum_{i=1}^{N}\left(M R_{i, p r e}-M R_{i, \exp }\right)^{2}}{N}}
$$

The higher values of $\mathrm{R}^{2}$, lower values of RMSE indicate better fitness of drying curves according to the moisture and time data.

\subsection{Moisture content}

Samples (1.0g) of chui jhal were weighed in triplicate with an analytical balance (Shimadzu AY220, Japan) and then placed in an oven (Jeio Tech, ModelOF-21E, Korea) for moisture removal at $105{ }^{\circ} \mathrm{C}$ for $24 \mathrm{hr}$. After drying, samples were placed in a desiccator to cool down temperature and weighed until no difference observed between two consecutive weight. The percentage of moisture content was calculated using following equation (4).

$$
\text { MC } \%=\frac{w_{0}}{w_{i}} \times 100
$$

where, Wo $=$ loss in weight $(\mathrm{g})$ on drying

$\mathrm{W}_{\mathrm{i}}=$ initial weight of the sample (g)

\subsection{Shrinkage}

Volume changes due to shrinkage of the samples were measured as described by Sjöholm [15] with slight modification. A $50 \mathrm{ml}$ measuring cylinder was filled with $10 \mathrm{ml}$ of toluene and $4 \mathrm{~g}$ of fresh sample was put on to it, and the increased amount was noted. The dried sample volume was also measured similarly. The measurement was done as quickly as possible (less than $30 \mathrm{sec}$ ) to avoid liquid uptake. Shrinkage volume change was expressed as a bulk shrinkage ratio.

$$
S=\frac{V}{V_{o}}
$$

where $\mathrm{Vo}_{\mathrm{o}}$ initial volume, $\mathrm{V}=$ volume after drying,

\subsection{Ascorbic acid content}

The determination of Ascorbic acid (AA) was adapted from Rangana S. [16] based on reducing 2, 6- dichlorophenol-indophenol by ascorbic acid and reduction of dehydroascorbic acid with 2, 4-dinitrophenylhydrazine. The ascorbic acid content of the chui jhal sample was expressed as $\mathrm{mg} / 100 \mathrm{~g}$.

\subsection{Total phenolic content}

Total phenolic content in the samples was assessed using the Folin-Ciocalteau assaywith slight modification. The sample (1.0 g) was mixed with $10 \mathrm{ml}$ of acetone (80 \%) and kept in shaking incubator (SI-100, Korea) for $90 \mathrm{~min}$. Then, centrifuged at $3000 \mathrm{rpm}$ (Gyrozen, $416 \mathrm{G}$, Korea) for $15 \mathrm{~min}$ and filtered through filter paper (Whatman no. 1). This extract was used for polyphenol determination. For the analysis, $20 \mu \mathrm{L}$ each of extract, Gallic acid standard or blank were taken in separate test tubes and to each $1.58 \mathrm{~mL}$ of distilled water was added, followed by $100 \mu \mathrm{L}$ of Folin-Ciocalteau reagent, then mixture mixed well and within 8 min $300 \mu \mathrm{L}$ of sodium carbonate was added in each. The samples were vortexed (VM-2000, Taiwan) immediately and the tubes were incubated in the dark for 30 min at $40{ }^{\circ} \mathrm{C}$. The absorbance was then measured at $765 \mathrm{~nm}$ in a UV-Vis spectrophotometer (Shimadzu, UV-1800, Japan). The results 
were expressed in mg Gallic acid equivalent (mg GAE)/100g [17]. The standard gallic acid curve was prepared to obtain the equation for total phenol content.

\subsection{Capsaicin content}

The capsaicin content of chui jhal samples was determined by the colorimetric method as explained by S. Sadasivam and A. Manickam [18]. In a $100 \mathrm{ml}$ volumetric flask, $500 \mathrm{mg}$ of chui jhal powder sample was taken, followed by $10 \mathrm{ml}$ of dry acetone. The obtained mixture was shaken in a mechanical shaker for $3 \mathrm{~h}$ and centrifuged at 10,000 rpm for 10 $\mathrm{min}$. One $\mathrm{ml}$ of clear supernatant was pipetted into a test tube and evaporated into a hot water bath to dryness. To this residue, $5 \mathrm{ml}$ of $\mathrm{NaOH}(0.4 \%)$ and $3 \mathrm{ml}$ of phosphomolybdic acid (3\%) were dissolved. After one hour of standing, the filtered solution was rapidly transferred into centrifuge tubes and centrifuged at $5000 \mathrm{rpm}$ for $15 \mathrm{~min}$. The supernatant absorbance was measured at $650 \mathrm{~nm}$ against a reagent blank in a UV-Vis spectrophotometer (Shimadzu, UV-1800, Japan). The standard graph was prepared using 0.2-1.0 ml of standard capsaicin containing 0-200 $\mu \mathrm{g}$ capsaicin.

\subsection{Measurement of color}

Chui jhal sample color parameters were determined with a colorimeter (PCE-CSM4, UK) method described by Islam [19]. The color values for foods can be indicated by the color values CIE, $\mathrm{L}^{*}, \mathrm{a} *$, and $\mathrm{b} *$ in this color coordination system. $L^{*}$ displays lightness or blackness (black, $L^{*}=0$, white, $L^{*}=100$ ), a * indicates redness or greenness (greenness, $a^{*}<0$; redness, $a^{*}>0$ ), and $b^{*}$ reflects yellowness or blueness (yellowness, $b^{*}>0$; blueness, $b^{*}<0$ ). The dried samples have been ground into a powder to the glass diaphragm. The color was then measured on the glass slide with the Chroma Meter. At least three measurements have been done for each sample at different locations, and the mean value recorded. The change of color can be represented as a full color (TableE), a combination of $\mathrm{L} *$, a $* \mathrm{~b}$ * values, determined by the following formula:

$$
\Delta E=\sqrt{\left(L^{*}{ }_{o}-L^{*}\right)^{2}+\left(a^{*}{ }_{o}-a^{*}\right)^{2}+\left(b^{*}{ }_{o}+b^{*}\right)^{2}}
$$

where $L^{*} 0, a^{*} 0$, and $b^{*} 0$ are the fresh chui jhal sample reading, while, after drying $L^{*}, a^{*}$, and $b^{*}$ are the final color values.

\subsection{Statistical analysis}

The measurements were performed in triplicates and were presented as mean \pm standard deviation. Statistical analysis was carried using SPSS software (SPSS Inc., Chicago, IL, USA). The statistical difference was evaluated using a one-way analysis of variance (ANOVA), and statistically relevant differences with p-values among treatments $<0.05$ were considered.

\section{Results and discussion}

\subsection{Moisture content and shrinkage}

Moisture content is a vital factor that helps to measure a food product's quality, shelf life, microbial activity, and other properties. Based on the findings in Table 2, the average moisture content of fresh chui jhal stem was $88.48 \%$, which decreased after pretreated hot-air drying at different temperatures. A lower percentage of moisture content was found in microwave (MWV) pretreatment compare to other pretreatments. The average moisture contents of MWB pretreated samples were found $11.98 \%, 11.65 \%$, and $10.67 \%$ percent at 50,60 , and $70{ }^{\circ} \mathrm{C}$ temperature, respectively. This significantly lower moisture in microwave treatment may be due to the faster heat generation throughout the product volumetrically rather than on slow heat conduction across its surface [20]. On the other hand, hot water blanching treated samples showed higher moisture content, which may be due to the direct immerging of products into hot water. The moisture content at the lower temperature remained higher for each pretreatment and deceased with higher temperatures.

All the values are mean \pm S.D of three independent determinations. The means with different subscripts differ significantly $(\mathrm{p} \leq 0.05)$.

Shrinkage during drying operations is known to be an indication of physical degradation. Table 1 shows that the shrinkage percentage for UT samples increased with increasing the temperature and established the maximum shrinkage of $65 \%$. On the contrary, the lowest shrinkage rates were observed in SB samples at three different temperatures, around 30 percent. This study evident that SB minimizes the loss of solid content during processing. Again, drying at $50{ }^{\circ} \mathrm{C}, 60$ ${ }^{\circ} \mathrm{C}$, and $70{ }^{\circ} \mathrm{C}$ temperature, MWB samples showed a higher percentage of shrinkage, 53.46\%, 56.44\%, and 53.62\%, respectively. This indicates that MWV treatment may not effectively protect the chui jhal samples from physical damage during drying. 
Table 2. Physical properties of pretreated hot air-dried chui jhal

\begin{tabular}{cccc}
\hline Pretreatments & Temperature $\left(\mathbf{~}^{\mathbf{C}} \mathbf{)}\right.$ & Moisture content $(\mathbf{\%}) \mathbf{( w b )}$ & Shrinkage (\%) \\
\hline Fresh & - & $88.48 \pm 0.17$ & - \\
Untreated (UT) & 50 & $15.71 \pm 0.13$ & $45.32 \pm 0.31$ \\
& 60 & $13.65 \pm 0.10$ & $56.54 \pm 0.25$ \\
Microwave (MWV) & 70 & $12.48 \pm 0.14$ & $65.73 \pm 0.46$ \\
& 50 & $11.98 \pm 0.12$ & $53.46 \pm 0.86$ \\
Hot water blanching & 60 & $11.65 \pm 0.13$ & $56.44 \pm 0.42$ \\
(HWB) & 70 & $10.67 \pm 0.15$ & $53.62 \pm 0.28$ \\
& 50 & $15.23 \pm 0.11$ & $37.47 \pm 0.45$ \\
Steam blanching (SB) & 60 & $14.96 \pm 0.14$ & $25.55 \pm 0.88$ \\
& 70 & $10.78 \pm 0.10$ & $29.14 \pm 0.45$ \\
\hline
\end{tabular}

\subsection{Ascorbic acid content}

The fresh chui jhal stem contained 51.38\% ascorbic acid. Table 3 represents the ascorbic acid content was retained higher in steam blanched samples $20.1 \%, 14.6 \%$, and $12.2 \%$, at $50{ }^{\circ} \mathrm{C}, 60^{\circ} \mathrm{C}$, and $70{ }^{\circ} \mathrm{C}$, respectively. In contrast, hot water blanching retained lower ascorbic acid $12.1 \%, 7.5 \%$, and $6.5 \%$, at $50{ }^{\circ} \mathrm{C}, 60{ }^{\circ} \mathrm{C}$, and $70{ }^{\circ} \mathrm{C}$, respectively. Gamboa-Santos et al. [21] have reported that steam blanching carrots with higher vitamin $\mathrm{C}$ retention (81.2\%) than those blanched in the water at $60{ }^{\circ} \mathrm{C}(1.3 \%)$, likely due to the leaching effect of hot water blanching. Moreover, steam blanching can cause an inactive biological enzyme because of the high degree of enthalpy. Again, the inactivation of oxidase in steam blanched samples allows the material to be increased by the cell membrane permeability, such as phenols in blueberries [22]. HWB samples could not retain this water-soluble nutrient because of its long drying time [23]. The MWB samples were contain $6.7 \%, 4.2 \%$, and $3.8 \%$ ascorbic acid after drying at $50{ }^{\circ} \mathrm{C}, 60{ }^{\circ} \mathrm{C}$, and $70{ }^{\circ} \mathrm{C}$, respectively, which were less than other treatments possibly due to a limited penetration depth of microwave create nonuniform microwave heating [24].

Table 3. Physical properties of pretreated hot air-dried chui jhal

\begin{tabular}{|c|c|c|c|c|c|c|c|}
\hline Pretreatments & $\begin{array}{c}\text { Temperature } \\
\left({ }^{\circ} \mathrm{C}\right)\end{array}$ & $\begin{array}{c}\text { Vit C } \\
\text { (mg/100g) }\end{array}$ & $\begin{array}{l}\text { Retention } \\
\text { (\%) }\end{array}$ & $\begin{array}{c}\text { TPC } \\
\text { (mgGAE/100g) }\end{array}$ & $\begin{array}{l}\text { Retention } \\
\text { (\%) }\end{array}$ & $\begin{array}{l}\text { Capsaicin } \\
(\mathrm{mg} / \mathbf{1 0 0 g})\end{array}$ & $\begin{array}{c}\text { Retention } \\
(\%)\end{array}$ \\
\hline Fresh & & $51.3 \pm 0.91 \mathrm{a}$ & & $3.70 \pm 0.88 \mathrm{a}$ & & $45.47 \pm 0.35 a$ & \\
\hline \multirow{3}{*}{$\begin{array}{l}\text { Untreated } \\
\text { (UT) }\end{array}$} & 50 & $4.65 \pm 0.35$ de & 9.0 & $53.59 \pm 1.071$ & 14.4 & $25.16 \pm 0.35 \mathrm{e}$ & 55.3 \\
\hline & 60 & 4.05 \pm 0.38 de & 7.8 & $123.01 \pm 0.64 \mathrm{f}$ & 33.3 & $23.87 \pm 0.55$ ef & 52.4 \\
\hline & 70 & $3.15 \pm 0.91 \mathrm{f}$ & 6.1 & $104.41 \pm 0.57 \mathrm{~g}$ & 28.2 & $21.29 \pm 0.32 f$ & 46.8 \\
\hline \multirow{3}{*}{$\begin{array}{l}\text { Microwave } \\
\text { (MWB) }\end{array}$} & 50 & $6.76 \pm 0.67 \mathrm{~cd}$ & 13.1 & $58.65 \pm 0.12 \mathrm{k}$ & 15.8 & $35.48 \pm 0.64 b$ & 78.0 \\
\hline & 60 & $4.28 \pm 0.24$ de & 8.2 & $73.40 \pm 0.80 \mathrm{j}$ & 19.8 & $32.251 \pm 0.05 b c$ & 70.9 \\
\hline & 70 & $3.87 \pm 0.56 \mathrm{ef}$ & 7.5 & $83.45 \pm 0.36 \mathrm{i}$ & 22.5 & $29.03 \pm 0.81 \mathrm{~cd}$ & 63.8 \\
\hline \multirow{3}{*}{$\begin{array}{l}\text { Hot Water } \\
\text { (HWB) }\end{array}$} & 50 & $6.24 \pm 0.53 \mathrm{~cd}$ & 12.1 & $87.56 \pm 0.75 h$ & 23.6 & $23.22 \pm 0.88 \mathrm{ef}$ & 51.0 \\
\hline & 60 & $3.87 \pm 0.56 \mathrm{ef}$ & 7.5 & $153.65 \pm 1.65 d$ & 41.4 & $21.93 \pm 0.95 f$ & 48.2 \\
\hline & 70 & $3.38 \pm 0.27 \mathrm{de}$ & 6.5 & $160.54 \pm 0.63 c$ & 43.3 & $20.64 \pm 0.33 f$ & 45.4 \\
\hline \multirow{3}{*}{$\begin{array}{l}\text { Steam } \\
\text { Blanching } \\
\text { (SB) }\end{array}$} & 50 & $10.37 \pm 0.45 b$ & 20.1 & $140.47 \pm 0.31 \mathrm{e}$ & 37.9 & $32.06 \pm 0.36 c$ & 70.5 \\
\hline & 60 & $7.54 \pm 0.87 \mathrm{c}$ & 14.6 & $141.33 \pm 1.19 \mathrm{e}$ & 38.1 & $30.96 \pm 0.95 c$ & 68.0 \\
\hline & 70 & $6.31 \pm 0.84 \mathrm{~cd}$ & 12.2 & $171.20 \pm 0.48 b$ & 46.2 & 26.09₫0.99de & 57.3 \\
\hline
\end{tabular}


All the values are mean \pm S.D of three independent determinations. The means with different subscripts differ significantly $(\mathrm{p} \leq 0.05)$.

\subsection{Total polyphenol content (TPC)}

The TPC value found in fresh chui jhal was $3.70 \pm 0.88 \mathrm{GAE} \mathrm{mg} / 100 \mathrm{~g}$, while pretreated samples contained TPC from $58.65 \pm 0.12$ to $171.20 \pm 0.48 \mathrm{GAE} \mathrm{mg} / 100 \mathrm{~g}$. This demonstrates a positive impact of blanching pretreatments before the hot-air drying of chui jhal stem. Table 3 shows that the TPC retention percentage was more in steam blanched dried samples ranging between $37.9 \%$ and $46.2 \%$ at different temperatures. This may be because steam blanching improved cell membrane permeability, which enhances phenol extraction [22]. The finding confirms a previous study [25], in which steam-cooking broccoli increased overall phenolic content as well as glucosinolates relative to fresh broccoli.

\subsection{Capsaicin}

Capsaicin is responsible for the spicy sensation in chui jhal sample. During hot air drying, this bioactive content can be degraded. The amount of capsaicin in fresh chui jhal stem was found to be $45.47 \pm 1.05 \mathrm{mg} / 100 \mathrm{~g}$. Table 3 shows that the retention of capsaicin was almost higher in pretreated samples compared to untreated. However, hot water blanching pretreatment samples retained less capsaicin, around $48 \%$, which is lower than other pretreatments. This reduction may be due to the leaching effect of water-soluble contents during hot water blanching. In all pretreatment, the capsaicin content decreased with increasing temperature. The untreated sample dried at $50{ }^{\circ} \mathrm{C}$ contained $25.16 \mathrm{mg} / 100 \mathrm{~g}$ samples, while microwave, hot water, and steam blanched samples dried at $50{ }^{\circ} \mathrm{C}$ contained, $35.48 \mathrm{mg} / 100 \mathrm{~g}, 23.22 \mathrm{mg} / 100 \mathrm{~g}$, and $32.06 \mathrm{mg} / 100 \mathrm{~g}$, respectively. On the other hand, when the drying temperature increased to $70{ }^{\circ} \mathrm{C}$ the capsaicin was found $29.03 \mathrm{mg} / 100 \mathrm{~g}, 20.64 \mathrm{mg} / 100 \mathrm{~g}, 26.09 \mathrm{mg} / 100 \mathrm{~g}$, respectively for microwave, hot water, and steam blanched samples. So, it indicates that increasing drying temperature may influence capsaicin degradation. Arifin and Djaeni [26] also reported the same phenomena during the drying of pretreated red chili pepper.

\subsection{Color}

The CIE color parameters of the fresh chui jhal sample recorded at $70.05 \pm 3.10,8.54 \pm 0.50,25.37 \pm 0.39$, and 70.35 \pm 0.35 , respectively. According to the result shown on Table 4, when the temperature increased from $50{ }^{\circ} \mathrm{C}$ to $70{ }^{\circ} \mathrm{C}$, the $\mathrm{L}^{*}$ value of the untreated and all pretreated samples decreased significantly $(\mathrm{p} \leq 0.05)$. This indicates dried samples getting a dark color to compare to fresh samples. All pretreated dried samples microwave blanched samples showed the highest lightness value 68.48 to 60.48 at 50 to $70{ }^{\circ} \mathrm{C}$. This is possibly due to less drying time required for MWV treated example, the hence less oxidative reaction taking place, which helps to preserve better lightness.

Table 4. Color parameter of pretreated hot air-dried chui jhal

\begin{tabular}{cccccc}
\hline \multirow{2}{*}{ Pretreatments } & \multicolumn{5}{c}{ CIE color parameters } \\
& Drying Temp $\left({ }^{\circ} \mathbf{C}\right)$ & $\mathbf{L}^{*}$ & $\mathbf{a}^{*}$ & $\mathbf{b}^{*}$ & $\Delta \boldsymbol{E}^{*}$ \\
\hline Fresh & & $70.05 \pm 3.10$ & $8.54 \pm 0.50$ & $25.37 \pm 0.39$ & $70.35 \pm 0.35$ \\
Untreated (UT) & 50 & $50.62 \pm 0.35$ & $3.45 \pm 0.38$ & $7.25 \pm 0.48$ & $27.05 \pm 0.36$ \\
& 60 & $54.78 \pm 0.94$ & $4.97 \pm 0.04$ & $7.27 \pm .045$ & $23.95 \pm 0.44$ \\
Microwave (MWB) & 70 & $46.78 \pm 1.34$ & $4.387 \pm 0.55$ & $5.77 \pm 0.93$ & $30.70 \pm 0.29$ \\
& 50 & $68.48 \pm 1.33$ & $8.39 \pm 0.11$ & $12.52 \pm 0.61$ & $12.94 \pm 0.75$ \\
Hot water blanching & 60 & $65.23 \pm 0.02$ & $6.45 \pm .015$ & $9.42 \pm 0.53$ & $16.78 \pm 0.16$ \\
(HWB) & 70 & $60.48 \pm 0.26$ & $4.03 \pm 0.29$ & $7.76 \pm 0.31$ & $20.54 \pm 0.21$ \\
& 50 & $60.67 \pm 0.04$ & $8.31 \pm 1.06$ & $15.34 \pm 0.94$ & $13.72 \pm 0.62$ \\
Steam blanching (SB) & 60 & $57.45 \pm 0.68$ & $7.88 \pm 0.99$ & $14.21 \pm 0.25$ & $16.84 \pm 0.33$ \\
& 70 & $51.48 \pm 0.79$ & $5.38 \pm 0.92$ & $11.38 \pm 0.86$ & $23.45 \pm 0.59$ \\
& 50 & $56.43 \pm 0.35$ & $14.24 \pm 0.35$ & $15.24 \pm 0.61$ & $17.90 \pm 0.77$ \\
& 60 & $49.76 \pm 0.21$ & $10.34 \pm 0.32$ & $12.21 \pm 0.42$ & $24.24 \pm 0.02$ \\
& 70 & $44.68 \pm 0.27$ & $6.56 \pm 0.36$ & $11.44 \pm 0.61$ & $29.00 \pm 0.61$ \\
\hline
\end{tabular}

All the values are mean \pm S.D of three independent determinations. The means with different subscripts differ significantly $(\mathrm{p} \leq 0.05)$.

On the other hand, the lowest lightness value was recorded 56.43 to 44.68 for SB samples, which means the darker 
surface appeared. Pretreated samples showed more $\mathrm{L} *$ (lightness), a * (redness), and $\mathrm{b} *$ (yellowness) than untreated samples. Blanching temperature and exposure time both have an impact on cell membranes [27]. Anthocyanin may release into the intercellular solvent. Once samples were blanched by hot water, and it led to a brighter surface. Liu et al. [28] also noticed that MWB shortened drying time and improved lightness ( $\mathrm{L}^{*}$ Value) of purple flesh sweet potato samples compared to SB and HWB. The $\Delta \mathrm{E}^{*}$ values also increased with drying temperature because of heat-sensitive components such as carbohydrates and proteins during drying at higher temperature non-enzymatic browning reaction and Maillard reaction taking place and produces dark pigments [29].

\subsection{Effects of pretreatments on drying characteristics of chui jhal stem}

Drying rate is defined as the moisture removed per unit time vs. drying period. The drying rate of the samples against drying time at $50{ }^{\circ} \mathrm{C}, 60{ }^{\circ} \mathrm{C}$, and $70{ }^{\circ} \mathrm{C}$, respectively, is shown in Figures 1(a), 1(b), and 1(c). Figures 1a-1c also demonstrated the drying characteristics of the untreated and pretreated chui jhal stem at these three different temperatures.
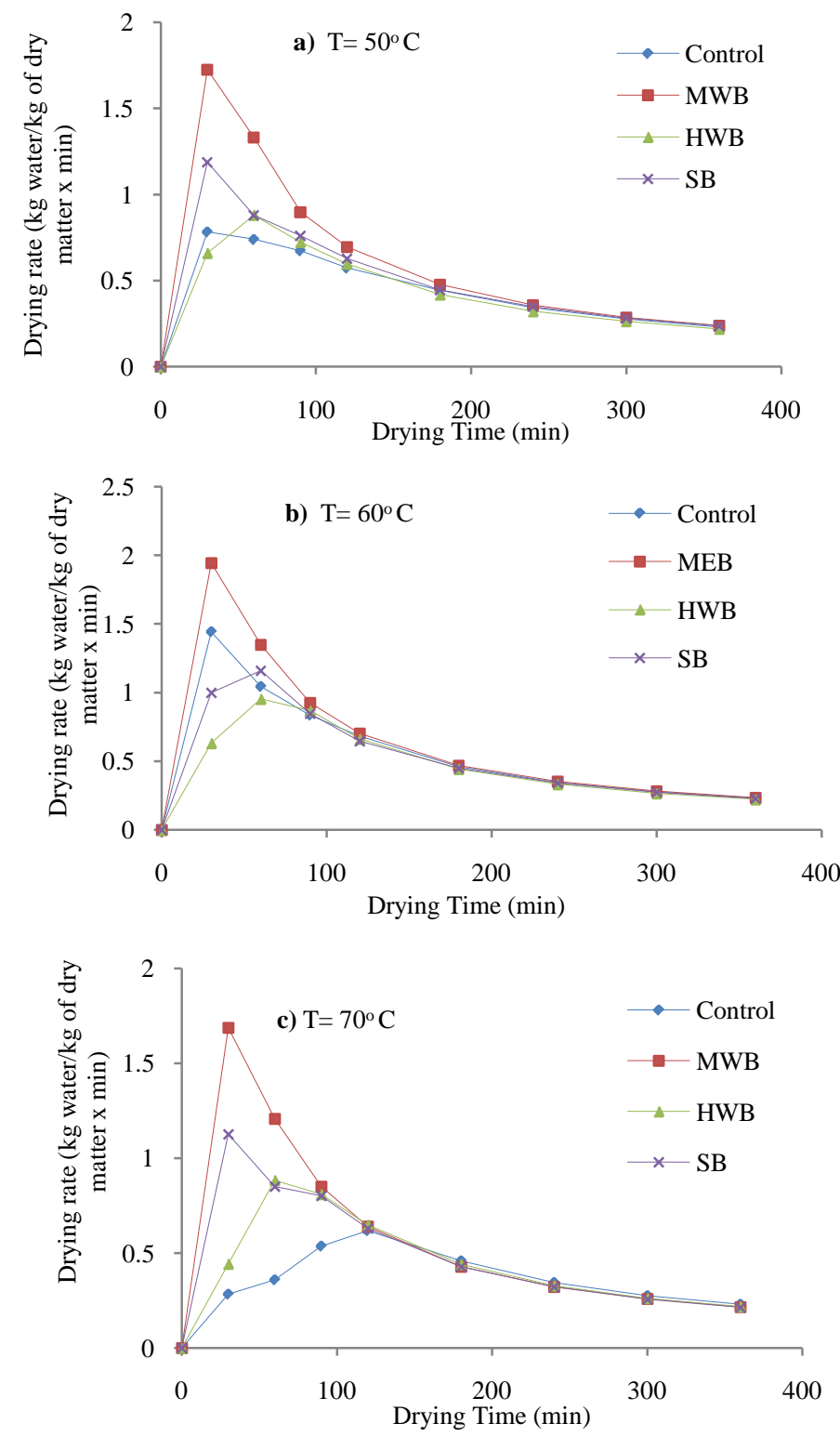

Figure 1. Drying curve of chui jhal stem dried at (a) $50^{\circ} \mathrm{C}$ (b) $60^{\circ} \mathrm{C}$ and (c) $70^{\circ} \mathrm{C}$

As shown in Figure 1, all curves have two stages, where the drying rate initially increases and then slowly declined with the drying period. In the falling rate period, the drying process occurred. MWV blanched sample showed the highest drying rate during drying at different temperatures. This can be due to the microwave's greater heating efficiency, 
and it takes less time to remove moisture. Besides, the drying rate decreases with increasing drying time. Figure 1 shows that the drying rate also changes with increasing drying temperature. This leads to higher temperatures and excessive water losses in terms of heat and mass transfer. The drying rate was much higher at the beginning of the drying process, and later on, it decreased with the samples' moisture content. This declination can be explained by the samples' porosity, which gets lowered due to the shrinkage and later on, developing resistance to further moisture movement [30]. Only the falling rate period was observed throughout the drying process. The higher amount of moisture was removed easily as surface moisture from the samples. According to Sharma and Prasad [31], while core humidity took longer, drying resulted in a falling rate.

\subsection{Fitting of drying curves}

The obtained drying data from different experiments were fitted into 3 moisture ratio models and statistical results from the modes are represented in Table 5 . As the basis for selecting the best model that explains the chui jhal stem slices' drying characteristics, a model with higher R2 and lower RMSE values was used. Based on the data collected, the Page model better explains the control and pretreatment drying characteristics of the samples, with $\mathrm{R}^{2}$ values varying from 0.999 to 0.987 and RMSE values from 0.005 to 0.071 .

Table 5. Estimated various model parameters for pretreated chui jhal stem during air drying

\begin{tabular}{|c|c|c|c|c|c|c|}
\hline \multirow{3}{*}{ Pretreatments } & \multicolumn{6}{|c|}{ Model Parameters } \\
\hline & \multicolumn{3}{|c|}{$\mathbf{R}^{2}$} & \multicolumn{3}{|c|}{ RMSE } \\
\hline & $50^{\circ} \mathrm{C}$ & $60^{\circ} \mathrm{C}$ & $70^{\circ} \mathrm{C}$ & $50^{\circ} \mathrm{C}$ & $60^{\circ} \mathrm{C}$ & $70^{\circ} \mathrm{C}$ \\
\hline \multicolumn{7}{|c|}{ Page Model } \\
\hline UT & 0.981 & 0.925 & 0.780 & 0.046 & 0.093 & 0.163 \\
\hline SB & 0.969 & 0.992 & 0.965 & 0.005 & 0.046 & 0.124 \\
\hline MW & 0.999 & 0.962 & 0.987 & 0.630 & 0.060 & 0.233 \\
\hline HW & 0.962 & 0.975 & 0.892 & 0.065 & 0.065 & 0.117 \\
\hline \multicolumn{7}{|c|}{ Henderson model } \\
\hline UT & 0.799 & 0.896 & 0.413 & 0.149 & 0.110 & 0.266 \\
\hline SB & 0.184 & 0.393 & 0.637 & 0.292 & 0.231 & 0.189 \\
\hline MW & 0.178 & 0.896 & 0.462 & 0.273 & 0.100 & 0.277 \\
\hline HW & 0.677 & 0.705 & 0.654 & 0.193 & 0.173 & 0.210 \\
\hline \multicolumn{7}{|c|}{ Lewis model } \\
\hline UT & 0.859 & 0.881 & 0.950 & 0.124 & 0.118 & 0.077 \\
\hline SB & 0.837 & 0.996 & 0.966 & 0.130 & 0.018 & 0.057 \\
\hline MW & 0.944 & 0.950 & 0.827 & 0.071 & 0.069 & 0.157 \\
\hline HW & 0.687 & 0.993 & 0.987 & 0.190 & 0.026 & 0.040 \\
\hline
\end{tabular}

The value of R2 and RMSE in SB treated samples ranges from 0.992 to 0.965 and 0.021 to 0.056 , respectively. In MWB pretreated samples, higher R2 (0.997 to 0.989) and lower RMSE (0.013 to 0.027) range were also observed. Similar observations were reported by Sarkar et al. [32] for coconut slices and Azoubel et al. [33] for banana.

\section{Conclusion}

In this study, physical blanching pretreatment was applied before drying to retain more nutritional and functional properties of chui jhal (Piper chaba H.) stem. The microwave blanched sample showed lowest moisture content after drying, but the shrinkage value was higher, which means more physical degradation occurred during MWB pretreatment. Consequently, less vitamin C, and total polyphenol content were retained in MWV treated samples; on the contrary, highest capsaicin content and better color were preserved due to less drying period. However, steam blanched samples showed comparatively less shrinkage after drying at different temperatures and retained more ascorbic acid, polyphenol, and capsaicin content than other pretreated samples. The drying characteristics of all chui jhal stem samples were evaluated by drying models such as Page, Henderson, and Lewis. With a high R2 value and a low root mean square of RMSE error, the page model provided significant results. All models' experimental data can be clarified, including the Page model that better explains the microwave and steam blanched sample under different drying conditions. 
The pretreatment reduces thermal losses of different nutritional properties during drying and fastens the drying period. Further study must evaluate the volatile content, sensory properties, and storage time of the chui jhal stem.

\section{Acknowledgment}

The authors express their gratitude to the Department of Food Engineering and Tea Technology, Shahjalal University of Science and Technology for continuous materials support and technical assistance.

\section{Conflicts of interest}

The authors declare no competing interests exist.

\section{References}

[1] Bhandari, S. P. S., \& Babu, U. V. (1998). A Lignan from Piper chaba stems. Phytochemistry, 47(7), 1435-1436. https://doi.org/10.1016/s0031-9422(97)00681-x.

[2] Kirtikar, K. R., \& Basu, B. D. (1987). Indian Medicinal Plants, Piper chaba. International Book Distributors, 3, $2130-2131$. https://doi.org/10.1007/978-0-387-70638-2_1203.

[3] Jin, J., Zhang, J., Guo, N., Feng, H., Li, L., Liang, J., ... \& Deng, X. (2011). The Plant Alkaloid Piperine as a Potential Inhibitor of Ethidium Bromide Efflux in Mycobacterium Smegmatis. Journal of medical microbiology, 60(2), $223-229$. https://doi.org/10.1099/jmm.0.025734-0.

[4] Yilbas, B., Hussain, M., \& Dincer, I. (2003). Heat and Moisture Diffusion in Slab Products Due to Convective Boundary Condition. Heat and Mass Transfer, 39(5-6), 471-476. https://doi.org/10.1007/s00231-002-0323-X.

[5] Mrad, N. D., Boudhrioua, N., Kechaou, N., Courtois, F., \& Bonazzi, C. (2012). Influence of air drying temperature on kinetics, physicochemical properties, total phenolic content and ascorbic acid of pears. Food and bioproducts processing, 90(3), 433-441. https://doi.org/10.1016/j.fbp.2011.11.009.

[6] Yu, Y., Jin, T. Z., \& Xiao, G. (2017). Effects of pulsed electric fields pretreatment and drying method on drying characteristics and nutritive quality of blueberries. Journal of Food Processing and Preservation, 41(6), e13303. https://doi.org/10.1111/jfpp.13303.

[7] Xiao, H. W., Bai, J. W., Sun, D. W., \& Gao, Z. J. (2014). The application of superheated steam impingement blanching (SSIB) in agricultural products processing-A review. Journal of Food Engineering, 132, 39-47. https://doi.org/10.1016/j.jfoodeng.2014.01.032.

[8] Wang, J., Yang, X. H., Mujumdar, A. S., Wang, D., Zhao, J. H., Fang, X. M., ... \& Xiao, H. W. (2017). Effects of various blanching methods on weight loss, enzymes inactivation, phytochemical contents, antioxidant capacity, ultrastructure and drying kinetics of red bell pepper (Capsicum annuum L.). LWT, 77, 337-347. https://doi.org/10.1016/j.lwt.2016.11.070.

[9] Guida, V., Ferrari, G., Pataro, G., Chambery, A., Di Maro, A., \& Parente, A. (2013). The effects of ohmic and conventional blanching on the nutritional, bioactive compounds and quality parameters of artichoke heads. LWT-Food Science and Technology, 53(2), 569-579. https://doi.org/10.1016/j.lwt.2013.04.006.

[10] Deng, L. Z., Mujumdar, A. S., Zhang, Q., Yang, X. H., Wang, J., Zheng, Z. A., ... \& Xiao, H. W. (2019). Chemical and physical pretreatments of fruits and vegetables: Effects on drying characteristics and quality attributes-a comprehensive review. Critical reviews in food science and nutrition, 59(9), 1408-1432. https://doi.org/10.1080/10408398.2017.1409192.

[11] Bingol, G., Wang, B., Zhang, A., Pan, Z., \& McHugh, T. H. (2014). Comparison of water and infrared blanching methods for processing performance and final product quality of French fries. Journal of Food Engineering, 121, $135-142$. https://doi.org/10.1016/j.jfoodeng.2013.08.001.

[12] Cheng, L. S., Fang, S., \& Ruan, M. L. (2015). Influence of blanching pretreatment on the drying characteristics of cherry tomato and mathematical modeling. International Journal of Food Engineering, 11(2), 265-274. https://doi.org/10.1515/ijfe-2014-0218.

[13] Araújo, A. C., Oliveira, S. M., Ramos, I. N., Brandão, T. R., \& Silva, C. L. (2016). Influence of pretreatments on quality parameters and nutritional compounds of dried galega kale (Brassica oleracea L. var. Acephala). Food and Bioprocess Technology, 9(5), 872-881. https://doi.org/10.1007/s11947-016-1678-1.

[14] Başkaya Sezer, D., \& Demirdöven, A. (2015). The effects of microwave blanching conditions on carrot slices: optimization and comparison. Journal of Food Processing and Preservation, 39(6), 2188-2196. https://doi.org/10.1111/jfpp.12463.

[15] Sjöholm, I., \& Gekas, V. (1995). Apple shrinkage upon drying. Journal of food engineering, 25(1), 123-130. https://doi.org/10.1016/0260-8774(94)00001-p.

[16] Ranganna, S. (1986). Handbook of analysis and quality control for fruit and vegetable products. Tata McGraw-Hill Education.

[17] Reddy, C. V. K., Sreeramulu, D., \& Raghunath, M. (2010). Antioxidant Activity of Fresh and Dry Fruits Co monly Consumed in India. Food research international, 43(1), 285-288. https://doi.org/10.1016/j.foodres.2009.10.006. 
[18] Sadasivam, S. (1996). Biochemical methods. New age international. 2: 200. https://doi.org/10.1016/s0165-022x(96)90012-3.

[19] Islam, M. Z., Saha, T., Monalisa, K., \& Hoque, M. M. (2019). Effect of Starch Edible Coating on Drying Characteristics and Antioxidant Properties of Papaya. Journal of Food Measurement and Characterization, 13(4), $2951-2960$. https://doi.org/10.1007/s11694-019-00215-3.

[20] Rahath Kubra, I., Kumar, D., \& Jagan Mohan Rao, L. (2016). Emerging trends in microwave processing of spices and herbs. Critical reviews in food science and nutrition, 56(13), 2160-2173. https://doi.org/10.1080/10408398.2013.818933.

[21] Gamboa-Santos, J., Montilla, A., Soria, A. C., \& Villamiel, M. (2012). Effects of conventional and ultrasound blanching on enzyme inactivation and carbohydrate content of carrots. European Food Research and Technology, 234(6), 1071-1079. https://doi.org/10.1007/s00217-012-1726-7.

[22] Del Bo’, C., Riso, P., Brambilla, A., Gardana, C., Rizzolo, A., Simonetti, P., ... \& Porrini, M. (2012). Blanching improves anthocyanin absorption from highbush blueberry (Vaccinium corymbosum L.) purée in healthy human volunteers: a pilot study. Journal of agricultural and food chemistry, 60(36), 9298-9304. https://doi.org/10.1021/jf3021333.

[23] Garba, U., Kaur, S., Gurumayum, S., \& Rasane, P. (2015). Effect of hot water blanching time and drying temperature on the thin layer drying kinetics of and anthocyanin degradation in black carrot (Daucus carota L.) shreds. Food Technology and Biotechnology, 53(3), 324-330. https://doi.org/10.17113/ftb.53.03.15.3830.

[24] Koskiniemi, C. B., Truong, V. D., Simunovic, J., \& McFeeters, R. F. (2011). Improvement of heating uniformity in packaged acidified vegetables pasteurized with a $915 \mathrm{MHz}$ continuous microwave system. Journal of food engineering, 105(1), 149-160. https://doi.org/10.1016/j.jfoodeng.2011.02.019.

[25] Gliszczyńska-Świgło, A., Ciska, E., Pawlak-Lemańska, K., Chmielewski, J., Borkowski, T., \& Tyrakowska, B. (2006). Changes in the content of health-promoting compounds and antioxidant activity of broccoli after domestic processing. Food Additives and Contaminants, 23(11), 1088-1098. https://doi.org/10.1080/02652030600887594.

[26] Arifin, U. F., \& Djaeni, M. (2018). Thermal Degradation Kinetics of Capsaicin on Blanching-Brine-Calcium Pretreatment Red Chili Pepper Drying. Bulletin of Chemical Reaction Engineering \& Catalysis, $13(2), \quad 365-372$. https://doi.org/10.9767/bcrec.13.2.1660.365-372.

[27] Ezekiel, R., Singh, N., Sharma, S., \& Kaur, A. (2013). Beneficial phytochemicals in potato-a review. Food Research International, 50(2), 487-496. https://doi.org/10.1016/j.foodres.2011.04.025.

[28] Liu, P., Mujumdar, A. S., Zhang, M., \& Jiang, H. (2015). Comparison of three blanching treatments on the color and anthocyanin level of the microwave-assisted spouted bed drying of purple flesh sweet potato. Drying Technology, 33(1), 66-71. https://doi.org/10.1080/07373937.2014.936558.

[29] Nguyen, M. L., \& Schwartz, S. J. (1999). Lycopene: Chemical chemical and biological properties: Developing nutraceuticals for the new millenium. Food Technology (Chicago), 53(2), 38-45.

[30] Singh, B., Panesar, P. S., \& Nanda, V. (2006). Utilization of carrot pomace for the preparation of a value added product. World Journal of Dairy \& Food Sciences, 1(1), 22-27. https://doi.org/10.1111/j.1745-4549.2006.00098.x.

[31] Sharma, G. P., \& Prasad, S. (2004). Effective moisture diffusivity of garlic cloves undergoing microwave-convective drying. Journal of Food engineering, 65(4), 609-617. https://doi.org/10.1016/j.jfoodeng.2004.02.027.

[32] Sarkar, A., Ahmed, T., Alam, M., Rahman, S., \& Pramanik, S. K. (2020). Influences of Osmotic Dehydration on Drying Behavior and Product Quality of Coconut (Cocos nucifera). Asian Food Science Journal, 21-30. https://doi.org/10.9734/afsj/2020/v15i330153.

[33] Azoubel, P. M., Baima, M. D. A. M., da Rocha Amorim, M., \& Oliveira, S. S. B. (2010). Effect of ultrasound on banana cv Pacovan drying kinetics. Journal of Food Engineering, 97(2), 194-198. https://doi.org/10.1016/j.jfoodeng.2009.10.009. 